\title{
Psychiatric Quarterly
}

\section{Decision-making Capacity in Healthcare: Instruments Review and Reflections about its Assessment in the Elderly with Cognitive Impairment and Dementia --Manuscript Draft--}

\begin{tabular}{|c|c|}
\hline Manuscript Number: & PSAQ-D-20-00444 \\
\hline Full Title: & $\begin{array}{l}\text { Decision-making Capacity in Healthcare: Instruments Review and Reflections about its } \\
\text { Assessment in the Elderly with Cognitive Impairment and Dementia }\end{array}$ \\
\hline Article Type: & Review Article \\
\hline Keywords: & $\begin{array}{l}\text { Capacity assessment; Healthcare decision-making; Dementia; Mild cognitive } \\
\text { impairment. }\end{array}$ \\
\hline Corresponding Author: & $\begin{array}{l}\text { Ana Saraiva Amaral, Master Degree } \\
\text { University of Coimbra Faculty of Psychology and Social Sciences: Universidade de } \\
\text { Coimbra Faculdade de Psicologia e Ciências da Educação } \\
\text { Coimbra, PORTUGAL }\end{array}$ \\
\hline \multicolumn{2}{|l|}{$\begin{array}{l}\text { Corresponding Author Secondary } \\
\text { Information: }\end{array}$} \\
\hline Corresponding Author's Institution: & $\begin{array}{l}\text { University of Coimbra Faculty of Psychology and Social Sciences: Universidade de } \\
\text { Coimbra Faculdade de Psicologia e Ciências da Educação }\end{array}$ \\
\hline \multicolumn{2}{|l|}{$\begin{array}{l}\text { Corresponding Author's Secondary } \\
\text { Institution: }\end{array}$} \\
\hline First Author: & Ana Saraiva Amaral, Master Degree \\
\hline \multicolumn{2}{|l|}{ First Author Secondary Information: } \\
\hline \multirow[t]{4}{*}{ Order of Authors: } & Ana Saraiva Amaral, Master Degree \\
\hline & Rosa Marina Afonso, $\mathrm{PhD}$ \\
\hline & Mário Rodrigues Simões, PhD \\
\hline & Sandra Freitas, PhD \\
\hline \multicolumn{2}{|c|}{ Order of Authors Secondary Information: } \\
\hline Funding Information: & $\begin{array}{l}\text { Fundação para a Ciência e a Tecnologia Mrs. Ana Saraiva Amaral } \\
\text { (SFRH/BD/139344/2018) }\end{array}$ \\
\hline Abstract: & $\begin{array}{l}\text { The prevalence of neurodegenerative diseases has been significantly increasing in the } \\
\text { last decades, and it is expected to continue to grow. These health disorders can impair } \\
\text { patients' decision-making capacity in healthcare. The capacity to make healthcare } \\
\text { decisions is a fundamental pillar of informed consent, therefore, it should be carefully } \\
\text { assessed. Clinicians' assessment, when not supported by a standardized tool, has } \\
\text { revealed to be unreliable, so the recourse to an instrument of capacity assessment is } \\
\text { crucial. The present paper aims to identify and summarize published instruments of } \\
\text { healthcare decision-making capacity. To do so, a search of peer-reviewed articles in } \\
\text { English, Portuguese and Spanish was conducted. A total of eighteen articles, detailing } \\
\text { seventeen assessment instruments were selected. Instruments differ on format, } \\
\text { structure, assessed abilities and psychometric properties. Likewise, instruments' } \\
\text { targeted population also varies, with a few being specifically developed for patients } \\
\text { with dementia. Although a high number of instruments were found, there is still no gold } \\
\text { standard for healthcare decision-making capacity assessment. The lack of a gold } \\
\text { standard highlights the need for more research in this field, as well as an effort to } \\
\text { develop guidelines and normative data, in order to improve clinical practices. }\end{array}$ \\
\hline
\end{tabular}




\title{
Decision-making Capacity in Healthcare: Instruments Review and Reflections about its Assessment in the
} EIderly with Cognitive Impairment and Dementia

\author{
Ana Saraiva Amaral \\ Corresponding author. \\ PhD FCT grant (SFRH/BD/139344/2018), ORCID:0000-0003-1887-5027 \\ Email: anapaula@fcsaude.ubi.pt \\ University of Coimbra, Center for Research in Neuropsychology and Cognitive and Behavioral Intervention \\ (CINEICC), Faculty of Psychology and Educational Sciences (FPCEUC), Coimbra, Portugal; \\ Psychological Assessment and Psychometrics Laboratory (PsyAssessmentLab), Faculty of Psychology and \\ Educational Sciences (FPCEUC), University of Coimbra, Coimbra, Portugal; \\ Health Sciences Research Center (CICS), University of Beira Interior (UBI), Covilhã, Portugal.
}

\section{Rosa Marina Afonso}

Email: rmafonso@ubi.pt

Department of Psychology and Education, University of Beira Interior (UBI), Covilhã, Portugal;

Center for Health Technology and Services Research (CINTESIS- ICBAS), Porto, Portugal.

\section{Mário R. Simões}

Email: simoesmr@fpce.uc.pt

University of Coimbra, Center for Research in Neuropsychology and Cognitive and Behavioral Intervention (CINEICC), Faculty of Psychology and Educational Sciences (FPCEUC), Coimbra, Portugal;

Psychological Assessment and Psychometrics Laboratory (PsyAssessmentLab), Faculty of Psychology and Educational Sciences (FPCEUC), University of Coimbra, Coimbra, Portugal;

University of Coimbra, Faculty of Psychology and Educational Sciences (FPCEUC), Coimbra, Portugal.

\section{Sandra Freitas}

Email: sandrafreitas0209@gmail.com

University of Coimbra, Center for Research in Neuropsychology and Cognitive and Behavioral Intervention (CINEICC), Faculty of Psychology and Educational Sciences (FPCEUC), Coimbra, Portugal; 
Psychological Assessment and Psychometrics Laboratory (PsyAssessmentLab), Faculty of Psychology and Educational Sciences (FPCEUC), University of Coimbra, Coimbra, Portugal;

University of Coimbra, Faculty of Psychology and Educational Sciences (FPCEUC), Coimbra, Portugal.

\section{Declarations}

Funding: Ana Saraiva Amaral is a PhD student at University of Coimbra, supported with a national PhD grant from FCT (Fundação para a Ciência e a Tecnologia), the Portuguese public agency for science, technology and innovation.

Conflicts of interest/Competing interests: Not applicable.

Availability of data and material: Not applicable.

Code availability: Not applicable.

Ethics approval: Not applicable.

Consent: Not applicable.

Author contributions: All the authors participated actively in the study design, data collection and analysis and manuscript preparation. 
Decision-making Capacity in Healthcare

1 Decision-making Capacity in Healthcare: Instruments Review and Reflections about its Assessment in the

\section{Elderly with Cognitive Impairment and Dementia}

3

\section{Abstract}

5 The prevalence of neurodegenerative diseases has been significantly increasing in the last decades, and it is 6 expected to continue to grow. These health disorders can impair patients' decision-making capacity in healthcare.

7 The capacity to make healthcare decisions is a fundamental pillar of informed consent, therefore, it should be 8 carefully assessed. Clinicians' assessment, when not supported by a standardized tool, has revealed to be 9 unreliable, so the recourse to an instrument of capacity assessment is crucial. The present paper aims to identify 10 and summarize published instruments of healthcare decision-making capacity. To do so, a search of peer-reviewed 11 articles in English, Portuguese and Spanish was conducted. A total of eighteen articles, detailing seventeen 12 assessment instruments were selected. Instruments differ on format, structure, assessed abilities and psychometric 13 properties. Likewise, instruments' targeted population also varies, with a few being specifically developed for 14 patients with dementia. Although a high number of instruments were found, there is still no gold standard for 15 healthcare decision-making capacity assessment. The lack of a gold standard highlights the need for more research 16 in this field, as well as an effort to develop guidelines and normative data, in order to improve clinical practices.

17 Keywords: Capacity assessment; Healthcare decision-making; Dementia; Mild cognitive impairment.

\section{1. Introduction}

20 To provide medical care, physicians need to obtain informed consent form their patients. This presumption relies 21 on the bioethical principle which stands for people's right to decide what happens to their own body. However, in order to consider an informed consent as valid, three assumptions are required: disclosure of information,

23 voluntariness and capacity $[1,2]$. Capacity to make healthcare decisions has been generally understood 24 accordingly to Grisso and Appelbaum's [3] model of four abilities. This model describes four functional abilities 25 implied in healthcare decision-making and is based on the legal standards of competence to consent [4]. The four 26 abilities are understanding, appreciation, reasoning and expressing a choice [5]. Understanding regards the ability 27 to understand the disclosed information about the disease, as well as the risks and benefits of each treatment option. As for appreciation, it stands for the ability to apply the disclosed information to one's own problem.

29 Reasoning describes the process of weighing the risks and benefits of each treatment option, which allows the 
Decision-making Capacity in Healthcare

30 patient to reach a decision. Finally, expressing a choice refers to the ability of communicating a clear and 1

31 consistent decision through speech, write, or other mean [5].

32 The assessment of capacity to consent to treatment is a routinely procedure in clinical practice [6]. Although,

33 some situations require a more thorough assessment, specially cases of mild cognitive impairment, dementia or 34 other health issues related to cognitive impairment.

35 Frequently, capacity assessments are performed by clinicians in a non-structured way. However, clinical 36 assessment per se does not seem to be the most effective way to evaluate healthcare decision-making capacity, 37 since various studies have pointed out low interrater reliability between clinicians [4]. These limitations highlight 38 the need of a structured assessment of healthcare decision-making capacity, with recourse to a specific assessment 39 tool. Several instruments have been developed. This article aims to review the existing instruments, summarize 40 their content, administration procedures, psychometric properties, and reflect about their usefulness in people with 41 cognitive impairment and dementia.

\section{2. Method}

44 We conducted searches for English, Portuguese and Spanish papers, published between 1980 and 2018, describing instruments of decision-making assessment in healthcare. The search terms used were "capacity to consent to 46 treatment", "competence to consent to treatment", "healthcare decision-making" and "assessment tools" or 47 “assessment instruments". Searches were limited to peer-reviewed publications, and conducted in the following 48 databases: Web of Science (Web of Science Core Collection, Current Content Connect MEDLINE and Scielo), 49 EbscoHost (Psychology and Behavioral Sciences Collection, Cochrane database of Systematic Reviews, 50 Cochrane Clinical Answers, MEDLINE complete), Scopus, Wiley Online Library, Taylor \& Francis Online, 51 Clinical Key, Proquest Psychology Journals, and PubMed.

52 Search results are presented in the flowchart below (fig.1). Articles describing assessment tools of healthcare 53 decision-making capacity were included. For this purpose, assessment tools should have a standardized scoring 54 procedure. Articles containing guidelines for clinical assessment of healthcare decision-making capacity were excluded. Instruments of decision-making capacity in activities of daily living, advance directives, consent to clinical research, and healthcare decision-making capacity in children were also excluded. 
Decision-making Capacity in Healthcare

60

Fig.1 Flowchart of literature review

1

2

3

4

5

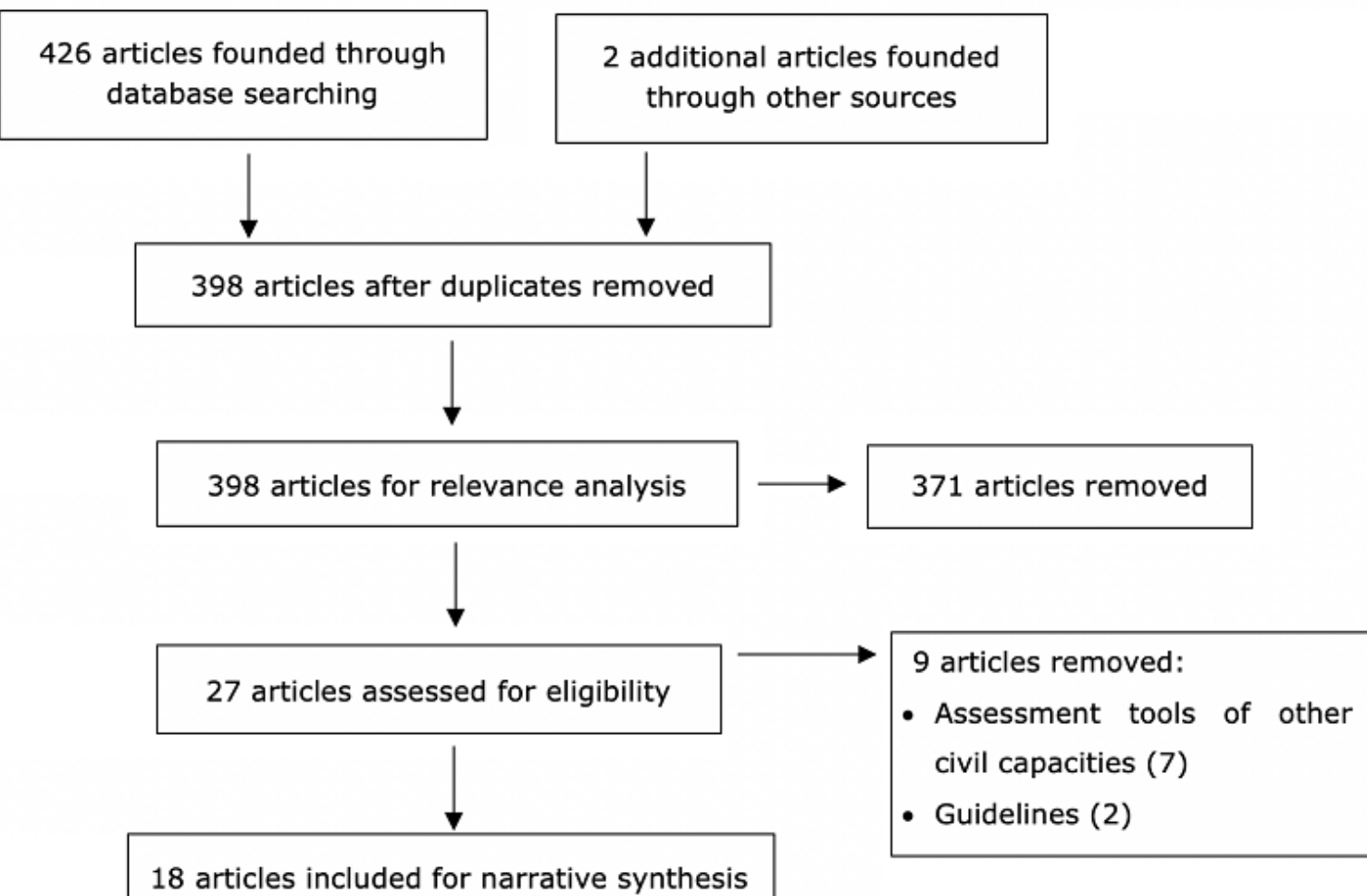

61

62

63 3. Results

64 Through online database research, 18 articles, describing 17 assessment instruments of healthcare decision-

65 making capacity were included. Each instrument main features are presented in Table 1. More detailed 66 descriptions can be found bellow. 
Decision-making Capacity in Healthcare

68 Table 1: Assessment tools of Decision-Making Capacity in Healthcare

\begin{tabular}{|c|c|c|c|c|c|c|}
\hline Instrument & $\begin{array}{l}\text { Application } \\
\text { Time }\end{array}$ & Format & Abilities included & Reliability & Cut-off scores & Pilot study participants \\
\hline $\begin{array}{l}\text { Two-Part } \\
\text { Consent Form } \\
{[7]}\end{array}$ & $\begin{array}{l}\text { No } \\
\text { information } \\
\text { available. }\end{array}$ & $\begin{array}{l}\text { Semi-structured } \\
\text { interview. }\end{array}$ & Understanding. & $\begin{array}{l}\text { Test-retest reliability, } r=.76 \text {; } \\
\text { Interrater reliability, } r=.96 \text {; } \\
\text { Agreement between judges, } \\
.5 \geq \mathrm{k} \leq .83 .\end{array}$ & $\begin{array}{l}\text { No information } \\
\text { available. }\end{array}$ & $\begin{array}{l}\text { Psychiatric patients referred to } \\
\text { electroconvulsive treatment. }\end{array}$ \\
\hline $\begin{array}{l}\text { Direct } \\
\text { Assessment of } \\
\text { Decision-Making } \\
\text { Capacity [8] }\end{array}$ & $\begin{array}{l}\text { No } \\
\text { information } \\
\text { available. }\end{array}$ & $\begin{array}{l}\text { Structured } \\
\text { interview with } \\
\text { clinical } \\
\text { vignettes. }\end{array}$ & $\begin{array}{l}\text { Understanding } \\
\text { Reasoning. }\end{array}$ & No information available. & $\begin{array}{l}\text { Bellow the lower } \\
99.5 \% \text { confidence } \\
\text { limit of control group } \\
\text { mean. }\end{array}$ & $\begin{array}{l}\text { Elderly inpatients with acute ill, } \\
\text { without neurologic or } \\
\text { psychiatric history. }\end{array}$ \\
\hline $\begin{array}{l}\text { Competency } \\
\text { Interview } \\
\text { Schedule [9] }\end{array}$ & $\begin{array}{l}\text { No } \\
\text { information } \\
\text { available. }\end{array}$ & $\begin{array}{l}\text { Structured } \\
\text { interview. }\end{array}$ & $\begin{array}{l}\text { Evidence a choice, } \\
\text { Understanding, } \\
\text { Appreciation and } \\
\text { Evidence rational } \\
\text { reasons for the choice. }\end{array}$ & $\begin{array}{l}\text { Test-retest reliability, } r=.79 ; \\
\text { Interrater reliability, ICC }= \\
.95 ; \text { Inter-item correlation } \\
\text { coefficients average }=.64 ; \\
\text { Cronbach's alpha }=.96 .\end{array}$ & $\begin{array}{l}\text { No information } \\
\text { available. }\end{array}$ & $\begin{array}{l}\text { Psychiatric inpatients with } \\
\text { recommendation to } \\
\text { electroconvulsive treatment. }\end{array}$ \\
\hline $\begin{array}{l}\text { Understanding } \\
\text { Treatment } \\
\text { Disclosure [10] }\end{array}$ & $\begin{array}{l}25-30 \\
\text { minutes }\end{array}$ & $\begin{array}{l}\text { Semi-structured } \\
\text { interview with }\end{array}$ & Understanding. & $\begin{array}{l}\text { Interrater reliability for } \\
\text { individual items } k \geq .60 \text { for } \\
90 \% \text { of the comparisons, and }\end{array}$ & $\begin{array}{l}\text { No information } \\
\text { available. }\end{array}$ & $\begin{array}{lr}\text { Hospitalized } & \text { groups: } \\
\text { Schizophrenia } & \text { or } \\
\text { Schizoaffective } & \text { Disorder; }\end{array}$ \\
\hline
\end{tabular}




\begin{tabular}{|c|c|c|c|c|c|c|}
\hline & & $\begin{array}{l}\text { clinical } \\
\text { vignettes. }\end{array}$ & & $\begin{array}{l}\text { ICC } \geq .84 \text { for subtests scores; } \\
\text { Test-retest reliability ranged } \\
\text { from } .50 \text { to } .80 \text {; Cronbach's } \\
\text { alpha ranged between } .55 \text { - } \\
.85 \text {. }\end{array}$ & & $\begin{array}{l}\text { Major Depressive Disorder; and } \\
\text { Ischemic Heart Disease. } \\
\text { Community groups. }\end{array}$ \\
\hline $\begin{array}{l}\text { Perceptions of } \\
\text { Disorder }[10]\end{array}$ & $\begin{array}{l}10-20 \\
\text { minutes }\end{array}$ & $\begin{array}{l}\text { Semi-structured } \\
\text { interview with } \\
\text { clinical } \\
\text { vignettes. }\end{array}$ & Appreciation. & $\begin{array}{l}\text { Test-retest reliability } \\
\text { between .48 and .90; } \\
\text { Cronbach's alpha between } \\
.67 \text { and } .80 \text {. }\end{array}$ & $\begin{array}{l}\text { No information } \\
\text { available. }\end{array}$ & $\begin{array}{l}\text { Hospitalized groups: } \\
\text { Schizophrenia } \\
\text { Schizoaffective Disorder; } \\
\text { Major Depressive Disorder; and } \\
\text { Ischemic Heart Disease. } \\
\text { Community groups. }\end{array}$ \\
\hline $\begin{array}{l}\text { Thinking } \\
\text { Rational About } \\
\text { Treatment }[10]\end{array}$ & $\begin{array}{l}25-30 \\
\text { minutes }\end{array}$ & $\begin{array}{l}\text { Semi-structured } \\
\text { interview with } \\
\text { clinical } \\
\text { vignettes. }\end{array}$ & $\begin{array}{l}\text { Reasoning and } \\
\text { Expressing a Choice. }\end{array}$ & $\begin{array}{l}\text { Interrater reliability, for } \\
\text { individual items } k \geq .60 \text { for } \\
76 \% \text { of the comparisons, and } \\
\text { ICC } \geq .88 \text { for total scores; } \\
\text { Test-retest reliability ranged } \\
\text { from } .66 \text { to } .68 \text {; Cronbach's } \\
\text { alpha between } .39-.74 \text {. }\end{array}$ & $\begin{array}{l}\text { No information } \\
\text { available. }\end{array}$ & $\begin{array}{l}\text { Hospitalized groups: } \\
\text { Schizophrenia } \\
\text { Schizoaffective Disorder; } \\
\text { Major Depressive Disorder; and } \\
\text { Ischemic Heart Disease. } \\
\text { Community groups. }\end{array}$ \\
\hline
\end{tabular}




\begin{tabular}{|c|c|c|c|c|c|c|}
\hline $\begin{array}{l}\text { MacArthur } \\
\text { Competence } \\
\text { Assessment Tool } \\
\text { for Treatment } \\
{[11]}\end{array}$ & $\begin{array}{l}15-20 \\
\text { minutes }\end{array}$ & $\begin{array}{l}\text { Semi-structured } \\
\text { interview. }\end{array}$ & $\begin{array}{l}\text { Understanding, } \\
\text { Appreciation, } \\
\text { Reasoning and } \\
\text { Expressing a choice. }\end{array}$ & $\begin{array}{l}\text { Interrater reliability, ICC }= \\
.99 \text { for understanding, } .87 \text { for } \\
\text { appreciation and } .91 \text { for } \\
\text { reasoning. }\end{array}$ & $\begin{array}{l}\text { No information } \\
\text { available. }\end{array}$ & $\begin{array}{l}\text { Hospitalized groups: } \\
\text { Schizophrenia } \\
\text { Schizoaffective Disorder; } \\
\text { Major Depressive Disorder; and } \\
\text { Ischemic Heart Disease. } \\
\text { Community groups. }\end{array}$ \\
\hline $\begin{array}{l}\text { Capacity to } \\
\text { Consent to } \\
\text { Treatment } \\
\text { Instrument [12] }\end{array}$ & $\begin{array}{l}20-25 \\
\text { minutes }\end{array}$ & $\begin{array}{l}\text { Structured } \\
\text { interview with } \\
\text { clinical } \\
\text { vignettes. }\end{array}$ & $\begin{array}{l}\text { Understanding, } \\
\text { Appreciation, } \\
\text { Reasoning, Expressing } \\
\text { a choice and Making a } \\
\text { reasonable choice. }\end{array}$ & $\begin{array}{l}\text { Interrater reliability, } r=.83 \\
\text { on interval scales and } 96 \% \\
\text { agreement on categorical } \\
\text { scales. }\end{array}$ & $\begin{array}{l}\text { Two standard } \\
\text { deviations below the } \\
\text { control group mean for } \\
\text { four abilities. }\end{array}$ & $\begin{array}{l}\text { Elderly with probable } \\
\text { Alzheimer's Disease and older } \\
\text { control group. }\end{array}$ \\
\hline SICIATRI [13] & 20 minutes & $\begin{array}{l}\text { Structured } \\
\text { interview. }\end{array}$ & $\begin{array}{l}\text { Awareness, Not waive } \\
\text { the right to decide, } \\
\text { Evidence a choice, } \\
\text { Understanding, Wants } \\
\text { to get better and Insight. }\end{array}$ & $\begin{array}{l}\text { Interrater reliability, for } \\
\text { individual items, .14 } \geq \mathrm{k} \leq \\
.82 \text {. }\end{array}$ & $\begin{array}{l}\text { No information } \\
\text { available. }\end{array}$ & $\begin{array}{l}\text { Psychiatric and } \\
\text { inpatients. }\end{array}$ \\
\hline $\begin{array}{l}\text { Hopemont } \\
\text { Capacity }\end{array}$ & $\begin{array}{l}30-60 \\
\text { minutes }\end{array}$ & $\begin{array}{l}\text { Semi-structured } \\
\text { interview with }\end{array}$ & $\begin{array}{l}\text { Understanding, } \\
\text { Appreciation } \\
\text { Reasoning. }\end{array}$ & $\begin{array}{l}\text { Interrater reliability has } \\
\text { consistently been of } .90 \text { or } \\
\text { more. }\end{array}$ & $\begin{array}{l}\text { No information } \\
\text { available. }\end{array}$ & $\begin{array}{l}\text { No information available. } \\
\text { However, the instrument was } \\
\text { designed to assess decision- }\end{array}$ \\
\hline
\end{tabular}




\begin{tabular}{|c|c|c|c|c|c|c|}
\hline $\begin{array}{l}\text { Assessment } \\
\text { Interview [14] }\end{array}$ & & $\begin{array}{l}\text { clinical } \\
\text { vignettes. }\end{array}$ & & & & $\begin{array}{l}\text { making in nursing home } \\
\text { residents. }\end{array}$ \\
\hline $\begin{array}{l}\text { Aid to Capacity } \\
\text { Evaluation [15] }\end{array}$ & $\begin{array}{l}10-20 \\
\text { minutes }\end{array}$ & $\begin{array}{l}\text { Semi-structured } \\
\text { interview. }\end{array}$ & $\begin{array}{l}\text { Understanding, } \\
\text { Appreciation } \\
\text { Reasoning. }\end{array}$ & Interrater reliability, $k=.79$, & $\begin{array}{l}\text { Overall impression of } \\
\text { probably or definitely } \\
\text { incapable according to } \\
\text { ACE classification, } \\
\text { associated with a score } \\
\text { between } 0-16 \text { on } \\
\text { Standardized Mini- } \\
\text { Mental Examination. }\end{array}$ & Medical inpatients. \\
\hline $\begin{array}{l}\text { Vignette method } \\
\text { described by } \\
\text { Schmand [16] }\end{array}$ & $\begin{array}{l}\text { No } \\
\text { information } \\
\text { available. }\end{array}$ & $\begin{array}{l}\text { Structed } \\
\text { interview, with } \\
\text { clinical } \\
\text { vignettes. }\end{array}$ & $\begin{array}{l}\text { Understanding, } \\
\text { Appreciation, } \\
\text { Reasoning and } \\
\text { Expressing a choice. }\end{array}$ & $\begin{array}{l}\text { Internal consistency of } .74 \text {; } \\
\text { Agreement between the } \\
\text { vignette method and clinical } \\
\text { judgment, } \mathrm{k}=.36 \text {. }\end{array}$ & $\begin{array}{l}\text { Fifth centile of control } \\
\text { group. }\end{array}$ & $\begin{array}{l}\text { Community dwelling elderly } \\
\text { with dementia syndromes } \\
\text { (minimal, mild and moderate) } \\
\text { and cognitively intact elderly. }\end{array}$ \\
\hline $\begin{array}{l}\text { Decision } \\
\text { Assessment } \\
\text { Measure [17] }\end{array}$ & $\begin{array}{l}\text { No } \\
\text { information } \\
\text { available. }\end{array}$ & $\begin{array}{l}\text { Semi-structured } \\
\text { interview }\end{array}$ & $\begin{array}{l}\text { Understanding and } \\
\text { Retaining information, } \\
\text { and Expressing a } \\
\text { choice. }\end{array}$ & Interrater reliability, $\mathrm{k}=.87$. & $\begin{array}{l}\text { No information } \\
\text { available. }\end{array}$ & $\begin{array}{l}\text { Groups with mental illness: } \\
\text { Dementia, learning disability } \\
\text { and schizophrenia or } \\
\text { schizoaffective disorder. } \\
\text { Control group. }\end{array}$ \\
\hline
\end{tabular}




\begin{tabular}{|c|c|c|c|c|c|c|}
\hline $\begin{array}{l}\text { Capacity } \\
\text { Assessment Tool } \\
{[18]}\end{array}$ & $\begin{array}{l}\text { A few } \\
\text { minutes, not } \\
\text { specified. }\end{array}$ & $\begin{array}{l}\text { Semi-structured } \\
\text { interview. }\end{array}$ & $\begin{array}{l}\text { Communication, } \\
\text { Understanding choices, } \\
\text { Comprehension of risks } \\
\text { and benefits, Insight, } \\
\text { Decision process and } \\
\text { Judgment }\end{array}$ & $\begin{array}{l}\text { Agreement between CAT } \\
\text { and Psychiatrist's evaluation, } \\
.77 \geq \mathrm{k} \leq 1 \text {. }\end{array}$ & $\begin{array}{l}\text { No information } \\
\text { available. }\end{array}$ & $\begin{array}{l}\text { Elderly hospitalized in a } \\
\text { Geriatric Unit or followed at the } \\
\text { Unit's consultation service. }\end{array}$ \\
\hline $\begin{array}{l}\text { Assessment of } \\
\text { Consent } \\
\text { Capacity - } \\
\text { Treatment [19] }\end{array}$ & 45 minutes & $\begin{array}{l}\text { Structured } \\
\text { interview with } \\
\text { clinical } \\
\text { vignettes. }\end{array}$ & $\begin{array}{l}\text { Understanding, } \\
\text { Appreciation, } \\
\text { Reasoning and } \\
\text { Expressing a Choice. }\end{array}$ & $\begin{array}{l}\text { Interrater agreement across } \\
\text { the } \\
\text { vignettes between } 97 \% \text { - } \\
98 \% \text {; Cronbach's alpha } \\
\text { between } .82 \text { and } .88 \text {. }\end{array}$ & $\begin{array}{l}\text { No information } \\
\text { available. }\end{array}$ & $\begin{array}{l}\text { Groups with mild and moderate } \\
\text { mental retardation. } \\
\text { Control group. }\end{array}$ \\
\hline $\begin{array}{l}\text { Vignette Method } \\
\text { by Vellinga [20] }\end{array}$ & $\begin{array}{l}\text { No } \\
\text { information } \\
\text { available. }\end{array}$ & $\begin{array}{l}\text { Structured } \\
\text { interview with } \\
\text { clinical } \\
\text { vignettes. }\end{array}$ & $\begin{array}{l}\text { Understanding, } \\
\text { Appreciation, } \\
\text { Reasoning and } \\
\text { Expressing a Choice. }\end{array}$ & Interrater reliability, $k=.64$. & $\begin{array}{l}\text { Fifth centile of the } \\
\text { control group. }\end{array}$ & $\begin{array}{l}\text { Elderly with dementia }(58,8 \%) \\
\text { and without }(37,5 \%) \text {. }\end{array}$ \\
\hline $\begin{array}{l}\text { Assessment of } \\
\text { Capacity to } \\
\text { Consent to } \\
\text { Treatment [21] }\end{array}$ & $\begin{array}{l}\text { No } \\
\text { information } \\
\text { available. }\end{array}$ & $\begin{array}{l}\text { Semi-structured } \\
\text { interview with } \\
\text { clinical } \\
\text { vignettes. }\end{array}$ & $\begin{array}{l}\text { Understanding, } \\
\text { Appreciation, } \\
\text { Reasoning and } \\
\text { Expressing a Choice. }\end{array}$ & $\begin{array}{l}\text { Interrater reliability, } r=.90 \text {; } \\
\text { Cronbach's alpha of } .96 .\end{array}$ & $\begin{array}{l}2 \text { standard deviations } \\
\text { bellow the control } \\
\text { group mean for } \\
\text { understanding, }\end{array}$ & $\begin{array}{l}\text { Elderly with dementia or } \\
\text { schizophrenia. } \\
\text { Control groups. }\end{array}$ \\
\hline
\end{tabular}


reasoning. 
Decision-making Capacity in Healthcare

70

1

2

3

4

5

\subsection{Two-Part Consent Form}

71 The Two-Part Consent Form was developed to assess capacity to consent electroconvulsive treatment in 72 psychiatric patients [7]. The first part presents information about electroconvulsive therapy and it is followed by 73 a questionnaire of fifteen items, which evaluate patients' understanding of the disclosed information.

74 Understanding is measured by recall tasks, language understanding and reasoning. Patients' answers are scored 75 between 0 and 2, with higher scores representing higher understanding. A total score can be obtained by summing 76 all individual scores. The pilot study was performed with a sample of psychiatric patients, to whom 77 electroconvulsive therapy had been recommended. The study included a total of fifty seven patients, forty four 78 who had consent electroconvulsive treatment, and thirteen who had refused it [7].

\section{$80 \quad 3.2$ Direct Assessment of Decision-Making Capacity}

81 Fitten and Waite [8] proposed an assessment tool to evaluate treatment decision-making capacity in elderly

82 patients with acute ill. This instrument presents three clinical vignettes of increased complexity, followed by a 83 structured interview. After each vignette's presentation participants are asked to make a decision about treatment.

84 The vignettes describe problems of insomnia, pleural effusion and resuscitation in chronical illness. The Direct 85 Assessment of Decision-Making Capacity assesses the ability to understand the medical problem, proposed 86 treatments, its risks and benefits, and reasoning. Patients' answers are scored as complete (2 points), partial (1 87 point) or no understanding of the question ( 0 points). Validation studies included twenty five inpatients over 60 88 years old, without history of neurologic or psychiatric problems and a control group with twenty five community89 dwelling volunteers. Inpatient participants showed significantly lower scores on the clinical vignettes [8].

\subsection{Competency Interview Schedule}

92 Developed by Bean and collaborators [9], Competency Interview Schedule (CIS) aims to evaluate psychiatric 93 patients capacity to consent to electroconvulsive therapy. CIS is a questionnaire of fifteen questions that assesses 94 the ability to evidence a choice, to understand information related to treatment, to appreciate the nature of the 95 situation and its consequences, and to evidence a rational reason for the choice made. Patients' answers are rated 96 in a Likert scale of seven points, where lower scores correspond to more adequate answers. Psychometric studies 97 were performed with a sample of ninety six subjects admitted to a psychiatric hospital, who had been diagnosed 98 with schizophrenia, schizoaffective, depression, mania, or other disorders [9]. 
Decision-making Capacity in Healthcare

\subsection{MacArthur Treatment Competence Study Instruments}

MacArthur Treatment Competence Study aimed to develop measures of competence to consent to treatment.

During its course, three instruments were developed Understanding Treatment Disclosure, Perceptions of 103 Disorder and Thinking Rational About Treatment. These instruments were designed based on the legal standards of capacity to consent to treatment: understanding, appreciation, reasoning and expressing a choice. The studies conducted included three clinical samples, named as hospitalized groups, and three community samples (nonhospitalized groups), with equivalent age, gender, ethnicity and socioeconomic status. The hospitalized groups included patients with schizophrenia or schizoaffective disorder $(n=75)$, major depressive disorder $(n=92)$ and ischemic heart disease $(n=82)$ [22].

Understanding Treatment Disclosure (UTD) is a structured interview that assesses the ability to understand information about treatment. It starts with the presentation of a standardized vignette disclosing information for informed consent. Three clinical vignettes were developed for this instrument, related to the disorders of the hospitalized groups. In the assessment with UTD, each vignette is first presented in an "uninterrupted disclosure" format, without any questioning occurring. After the uninterrupted disclosure, ten standardized questions are made. Then, the vignette is presented again, in an "element disclosure" format, with each paragraph presented at a time. Each paragraph is followed by standardized questioning, which contain questions demanding information recall and recognition tasks. Each answer is classified in a three-point Likert scale (0-2). There are no instructions for a total score, but for three sub-ranking-scales scores, which represent the scores obtained after the uninterrupted disclosure and element disclosure (information recall and recognition questions) [10].

119 Perceptions of Disorder (POD) assesses the ability to appreciate the situation and its consequences to one's own situation. Considering the three clinical groups, three forms of Perceptions of Disorder were developed. Each form is composed by three parts, but only two will be discussed, since research results of the third part have not 122 been found during the research. The first part is Non-Acknowledgment of Disorder and the second NonAcknowledgment of Treatment Potential. Each part presents a piece of information about the disorder and the treatment, respectively. After each part being presented, patients are asked to rate in a six-point scale how much they believe that the information applies to their own situation. Then, patients are asked to explain their reasons, which are rated between 0 and 2, with lower scores indicating greater non-acknowledgment [10, 23].

128 Competence Study. It measures the ability to reason or rational manipulate information, through the assessment 129 of cognitive functions involved in decision-making processes. This instrument is composed by two parts: 1) 
Decision-making Capacity in Healthcare

130

1

2131

3

4

5

6

7

8

9

10

11

12

13

vignette presentation, followed by a series of questions that measure five cognitive functions; and 2) three tasks, unrelated to the vignette, which assess three more cognitive functions. Therefore, TRAT has a total of eight questions, that are scored between 0 and 2. A total TRAT score may be obtained by summing the scores of the eight questions. The authors also developed a TRAT-2 score, that includes only six of the eight tasks. This instrument also includes one item to assess the ability to express a choice, which can be rated between 0 and 2 $[10,22]$.

\subsection{MacArthur Competence Assessment Tool for Treatment}

MacArthur Competence Assessment Tool for Treatment (MacCAT-T) was based on Treatment Competence Study. It merges the three previous instruments into a structured interview, which allows the assessment of understanding, appreciation, reasoning and expressing a choice. The MacCAT-T does not include clinical vignettes, so decision-making capacity is assessed in real-life context. The scoring criteria allows to classify patients' answers between 0 and 2, with higher scores representing more adequate responses. Based on the theoretical assumption that there are no universal levels of abilities which can distinct between competence and incompetence, no cut-off scores are proposed. In the same way, as an impairment in a specific ability could compromise decision-making capacity, there are no instructions for calculating a total MacCAT-T score. The MacCAT-T study was developed with a clinical sample of hospitalized patients with schizophrenia $(n=40)$ and a control group from community $(n=40)[11]$.

\subsection{Capacity to Consent to Treatment Instrument}

Capacity to Consent to Treatment Instrument (CCTI) is a structured interview developed to assess capacity to consent to treatment, especially in people with dementia. It contains two clinical vignettes, presenting a neoplasm 152 and a cardiac problem, where symptoms and two possible treatments are described. After each vignette being 153 presented (orally and in writing), patients are asked fourteen standardized questions. CCTI assesses the ability to express a treatment choice, make a reasonable choice, appreciate emotional and cognitive consequences of treatment, reasoning and understanding the medical condition and treatment choices. Patients' answers are scored according to two scoring systems: Quantitative and Qualitative scoring. The first scoring system rates patients' answers between 0 and 2 points. In the pilot study, scores of each ability were considered separately. A cut-off score of 2 standard deviations below the control group mean for the abilities express a treatment choice, appreciate consequences, reasoning and understanding was considered as an indicative of lack of competency. 
Decision-making Capacity in Healthcare

160 The Qualitative scoring system identifies sixteen types of errors, due to language dysfunction, executive dysfunction, affective dysfunction or compensatory responses [12]. A recent study proposes an experimental total score of CCTI. Age-independent and age-adjusted normative data for each ability and total CCTI score were also published, with a sample of three hundred eight community-dwelling adults, without cognitive impairment, between 19 and 86 years [24].

\subsection{Structured Interview for Competency and Incompetency Assessment Testing and Ranking Inventory}

The Structured Interview for Competency and Incompetency Assessment Testing and Ranking Inventory (SICIATRI) is a structured interview developed by Kitamura and Kitamura [13] for the assessment of competency in psychiatric patients [13]. SICIATRI is composed by twelve items that measure patient capacity to give informed consent for hospital admission or medication. The items assess the patients' awareness of being informed, do not waive the right to decide, evidence a choice, understanding the right to decide, understanding risks and benefits associated to treatment, alternative treatment or absence of treatment, wanting to get better, the absence of pathological determinants and insight. Answers are rated between 1 and 3, with lower scores representing worst performances. According to the score obtained, patients' performance is rated in one of the five levels of Ranking Inventory for Competency, which ranges from completely incompetent to completely competent. Validation studies included a sample of twenty five psychiatric and twenty three medical hospitalized patients between 21 and 80 years [13].

\subsection{Hopemont Capacity Assessment Interview}

Hopemont Capacity Assessment Interview (HCAI) is an interview in a semi-structured format, with two sections. The first section assesses the capacity to make healthcare decisions, and the second measures financial capacity. Only the first section will be considered in the present paper. Being so, HCAI assesses three core abilities: understanding, appreciation and reasoning. The interview starts by presenting the definitions of risk, benefit and having a choice, and next the patients are asked to explain the same definitions in their own words. After that, the interview proceeds with the presentation of two clinical vignettes (eye infection and advance directive), each followed by nine questions. HCAI may be scored by counting the number of correct answers, or assigning scores $(0,1$ or 2$)$ to each answer, with higher scores representing more adequate responses. Procedures to calculate total scores are not recommended, since the questions have different weights regarding decision-making capacity [14]. 
Decision-making Capacity in Healthcare

190

1

2191

3

4

5

6

7

8

9

10

11

12

\subsection{Aid to Capacity Evaluation}

Aid to Capacity Evaluation (ACE) is a semi-structured interview that assesses capacity to make healthcare decisions, based in patients' real health problem, not a standardized vignette. It evaluates the abilities: to understand information regarding the medical problem, proposed treatment, its alternatives, and the option of refusing treatment; reason about the consequences of refusing or accepting the treatment; and appreciation, which is conceptualized as the ability to make decisions not based on hallucinations, delusions or depression. Each question is scored as yes, if the patient gives an appropriate answer, as no, if the patient gives an inappropriate answer, or as unsure, when close-ended questions are necessary. After scoring ACE, the clinician should rate the patient as definitely capable, probably capable, probably incapable or definitely incapable [15].

\subsection{Vignette method described by Schmand}

Schmand and collaborators [16] studied the usefulness of a vignette method to evaluate capacity to consent to treatment and research in people with dementia. The pilot study included a sample of 240 subjects, distributed in control group $(n=176)$, minimal dementia $(n=14)$, mild dementia $(n=43)$ and moderate dementia $(n=7)$. The vignette method consists on the presentation of two clinical vignettes, describing a clinical trial and a hip fracture. After each vignette being integrally presented, a series of questions are asked. A total of sixteen questions evaluate understanding, appreciation, reasoning and expressing a choice. After rating patients' answers, competency scores of each vignette and a combined score may be calculated, by summing the number of correct answers. The authors [16] established cut-off scores of $95 \%$ of the control group mean, which indicate lack of capacity to consent to treatment and research.

\subsection{Decision Assessment Measure}

212 Decision Assessment Measure (DAM) is a semi-structured interview designed to evaluate decision-making 213 capacity in patients with mental disabilities. Target participants were patients who had been advised by their 214 physicians to have a blood test. The interview begins by asking the patients to say what they know about blood 215 tests. Then an information sheet about blood tests is presented. After information disclosure, patients are asked a series of questions that aim to assess their ability to understand and retain information, and to communicate a choice. When revealing lack of capacity in the first series of questions, each element of the information sheet is 218 presented at a time and it is followed by questioning and recognition tasks. After the questioning procedure, 219 patients are asked to perform a non-verbal demonstration, simulating a blood test with medical items. These must 
Decision-making Capacity in Healthcare

220 be chosen by the patient from a set of tools that include distracting items. Answers are rated according to a three-

1 point system (0-2), where greater scores indicate a better performance. Scores should be used to support clinicians’ judgment. For study purposes, three clinical samples were considered: group with schizophrenia or schizoaffective disorder $(n=21)$, learning disability group $(n=20)$, and dementia group $(n=21)$ [17].

\subsection{Capacity Assessment Tool}

226 Capacity Assessment Tool (CAT) was developed to allow a regular and time effective assessment of healthcare 227 decision-making capacity. It enables the assessment of decision-making capacity in real-life situations, so it does not contain clinical vignettes. CAT's score is based on six components, namely, communication, understanding choices, comprehension of risks and benefits, insight, decision process and judgment. Interviewees' answers are scored between $0-3$, or 0 and 1 . It is not recommended to calculate a total score, so each of the six components must be individually considered. Pilot studies included a sample of twenty patients from a Geriatric Inpatient Unit or Consultation Service [18].

\subsection{Assessment of Consent Capacity-Treatment}

Assessment of Consent Capacity - Treatment (ACC-T) is a structured interview developed to evaluate capacity to consent to treatment in adults with mental retardation. It contains three hypothetical vignettes regarding psychopharmacological treatment, placement of an orthodontic brace and administration of injections to prevent allergic reactions. The vignettes are presented a paragraph at a time, with each being followed by questions that compose a thirteen-item questionnaire. The questionnaire measures the four decisional abilities, and each answer 240 is scored accordingly to a three-point scale (between 0 and 2). There are no indications for calculating a total score, so each ability should be considered individually. Pilot study included a sample of ninety participants distributed in three groups: mild mental retardation, moderate mental retardation and no mental retardation [19].

\subsection{Vignette method described by Vellinga}

245 Vellinga and collaborators [20] compared three judgments of competency: a vignette method, family members' 246 judgment and physician's judgment. A total of eighty elderly, of whom 37,5\% had dementia, their physicians, and 247 eighty family members were included. The vignette method consists on presenting two clinical vignettes (anemia 248 and surgery for colon cancer), followed by a structured interview. The interview assesses understanding, 249 evidencing a choice, reasoning and appreciation. Patients' answers are scored between 0 and 2, with higher scores 
Decision-making Capacity in Healthcare

250

1

2251

3

4252

6253

7

8

10

11

12

representing better performance. A total score can be dichotomized into competent or incompetent performance, by a cut-off score of $95 \%$ of the sample without cognitive impairment [20].

\subsection{Assessment of Capacity to Consent to Treatment}

The Assessment of Capacity to Consent to Treatment (ACCT) is a semi-structured interview developed to assess consent capacity in patients with neurocognitive or neuropsychiatric diseases. It evaluates the four abilities of decision-making, namely understanding, appreciation, reasoning and communicating a choice, as well as values and preferences relevant to clinical decisions. The ACCT contains three clinical vignettes, the first reporting a case of rheumatoid arthritis, the second eliciting an advanced directive, and the third describing a leg ulcer. For clinical use, either the hypothetical vignettes or the patients' real medical problem can be used. In this sense, the ACCT has the advantage of containing vignettes and also allowing the interview to adapt to real-life situations. Pilot studies included a control group $(n=19)$ and two clinical groups, one with dementia $(n=20)$ and other with schizophrenia ( $n=20)$. For statistical purposes, Moye et al. (2007) calculated a summary dichotomous score, which classifies the patient has has capacity or lacks capacity. To do so, cut-off scores of 2.0 standard deviations from the control group mean were established for understanding, appreciation and reasoning. Participants who had scores below the cut-off on any of these abilities had a summary dichotomous score of lacks capacity [21].

\section{Discussion}

268 Through this narrative review, seventeen measures of healthcare decision-making capacity were identified. 269 Although the instruments intended to measure the same construct, they differ on what concerns the competencies 270 assessed and the methods employed.

\subsection{Assessed abilities}

Regarding the competencies assessed, most instruments are based on the four abilities model. However, only eight 274 instruments assess all the four abilities. Understanding is the only ability measured by all instruments, except for 275 two which aim to measure specific abilities (POD and TRAT). Understanding is commonly assessed by asking 276 the patients to paraphrase information disclosed in a hypothetical vignette or regarding their own medical problem. 277 Appreciation is measured in ten of the seventeen instruments. Nonetheless, there are major differences in how 278 this ability is assessed. On one hand, CIS, Perceptions of Disorder, MacCAT-T, HCAI and ACE operationalized appreciation as the acknowledgement of the significance of the information to one's own circumstance, 
Decision-making Capacity in Healthcare

280 recognition of the medical problem and potential benefits from the treatment [25]. In this way, appreciation is

1 understood as insight towards the medical problem and potential benefits of the treatment. On the other hand, CCTI, Vignette Method by Schman, ACC-T and Vignette Method by Vellinga defined appreciation as the ability to anticipate emotional and cognitive consequences from the treatment. By that, appreciation is conceptualized as a foresight capacity, in which the individual should be able to predict changes in his life due to the treatment [26, 27]. These inconsistencies are serious and result in statistical fragilities [21]. To overcome this divergence, the ACCT assesses appreciation employing two subscales: The Distrust subscale and the Foresight subscale, in an attempt to consider both of the previous interpretations. In fact, recent definitions of appreciation propose that this ability implies both the acknowledgment of the medical problem and potential benefits of treatment, and the anticipation of consequences related to the treatment $[26,28]$. Although these recent definitions allow to overcome the previous challenges on appreciation's conceptualization, they bring another conceptual challenge, discussed below.

292 Reasoning assessment is included in eleven instruments, in which the participants are asked to enumerate the risks and benefits they would have in mind when making a decision, and also to generate consequences of what might change in their daily lives due to the treatment. When asking patients to generate consequences, reasoning is being assessed as a foresight ability. However, as discussed before, appreciation as also been defined as the ability to foresee possible treatment consequences [26]. In this sense, there seems to be a risk of overlapping between appreciation and reasoning, which should be avoided.

298 Finally, expressing a choice is contemplated in ten of the seventeen instruments. This ability has been uniformly measured by asking the participant to choose an option.

300 A fifth ability, making a reasonable choice, is included in CCTI [12]. The first publications concerning the legal standards of competence to consent to treatment included this competence [29]. Making a reasonable choice consisted on the ability to choose the option that a reasonable person would choose. However, this ability has disappeared from the clinical setting, due to the arbitrariness of what may be considered reasonable. In fact, Gerstenecker and collaborators [24], instead of making a reasonable choice, designates this ability of the CCTI as making choice, which reveals the discontinuity of this ability in capacity assessments.

\subsection{Result interpretations}

Apart from the differences on the assessed abilities, the instruments also differ on scoring procedures and interpretations. In this respect, most of the instruments do not provide instructions for total scores nor cut-off 
Decision-making Capacity in Healthcare

310 scores. However, in Two-part Consent Form, the authors [7] computed total scores by summing all item scores.

1

Also, the authors of the Vignette method by Schmand [16] and the Vignette method by Vellinga [20] calculated total scores and established cut-off scores for lack of capacity to consent to treatment. Some authors disagree with this approach, since it assumes that low scores in an ability can be compensated by higher scores in another [30]. The CCTI [12] and the ACCT [21] propose cut-off scores for each ability, stating that the abilities should be individually considered. According to the four abilities model, in order to have decision-making capacity the patient must have preserved the four abilities, which may compromise the clinical usefulness of a total score [5].

\subsection{Information disclosure}

Another difference between the previous instruments regards the information disclosure, which may consist on the presentation of a hypothetical situation or the patient's real health problem. On the hypothetical situation, a clinical vignette describing a fictitious medical problem and treatment options is presented. Conversely, in the realistic situation patients receive information about their own health problem and treatment options [31]. Both approaches have advantages and disadvantages. On one hand, standardized clinical vignettes enable the development of normative data, which are useful in clinical settings and also allow group comparison in research field [21]. On the other hand, some authors state that decision-making capacity should be evaluated in the context of the decision at hand, because patients' performance could be different in hypothetical and realistic situations [30].

328 Few studies addressed this issue. Grisso and Appelbaum [32] studied the differences between hypothetical and 329 realistic situations regarding the ability to understand. They found that psychiatric samples showed better 330 understanding of information related to their own situation. However, non-psychiatric samples performed similarly in both hypothetical and realistic situations [32]. More recently, Vellinga and collaborators [33] found

332 no significant differences in mean scores of understanding, appreciation, reasoning and expressing a choice, nor 333 total mean score, between hypothetical and realistic situations. When comparing groups of impaired and non334 impaired cognitive functioning, cognitive impaired patients performed better on appreciating their own medical 335 problem and had a significant higher mean on total score. However, no significant differences were found on understanding, reasoning and expressing a choice [33]. Also, participants with cognitive impairment in the realistic group received the clinical information twice, which could had contributed to a better performance. These conclusions stand out the need for more investigation in this field. However, research shows that clinical vignettes 
Decision-making Capacity in Healthcare

339

1

2340

3

4341

5

can approximate real-life situations [12], and they provide valid information about patients' decision-making capacity [34], which stands for their usefulness in both research and clinical settings.

\subsection{Healthcare decision-making capacity assessment in cognitive impairment and dementia}

Among the reviewed instruments, three of them were designed to assess consent capacity in the older population, and five of them to evaluate consent capacity in patients with dementia. When assessing dementia patients' capacity to consent, it is important to use an instrument that has been specifically developed to assess capacity in these populations. Mild cognitive impairment and dementia symptoms affect cognitive functions relevant to decision-making, such as memory, attention and executive functions [35]. Due to this, capacity assessment tools should include strategies that allow to decrease the demand on such functions. For example, the ACCT, The Vignette Method by Schman and The Vignette Method by Vellinga include visual aids to reduce memory demands.

There are other factors which can impact capacity assessments, like the way by which information is presented [1]. Specifically, framing and phrasing of information can influence the decision-making process. Because of this, instruments' disclosure of information through clinical vignettes or description of patients' real problems should be designed in a way that facilitates their understanding of information and maximizes their capacity.

355 Healthcare values, beliefs and experience are also described as relevant to decision-making [36]. Regarding capacity assessments, coherence between patients expressed values and their treatment decisions can be an 357 indication of capacity, and research has shown that people with dementia appear to express their values as consistently as elderly without cognitive impairment [37]. However, only ACCT includes values assessment.

359 When comparing assessment instruments' targeting older adults or patients with dementia, it is possible to identify 360 discrepancies among the assessed abilities. Furthermore, research has identified significant differences in capacity 361 assessment results between different assessment tools. In this respect, Moye and collaborators [27] compared the results of CCTI, MacCAT-T and HCAI in a sample of elders with mild to moderate dementia and matched control groups. Study results showed differences on appreciation and reasoning assessments. Specifically, participants with dementia performed worse than control groups on appreciation when measured by CCTI, but according to MacCAT-T and HCAI. Similarly, participants with dementia performed worse than control group participants on reasoning, when measured by MacCAT-T and CCTI, but not when assessed by HCAI [27]. These inconsistencies reveal the need for more study in this area, in order to improve assessment tools' reliability. 
Decision-making Capacity in Healthcare

368 Another relevant improvement to healthcare decision-making capacity assessment would be the development of normative data. According to the research conducted, only CCTI developed normative data [24]. Nevertheless, undertaking more normative studies could be a valuable contribution to increase capacity assessments precision. Normative data provide a point of reference from which patients' performance can be compared to. Knowing what level of performance is expected for an adult within a specific age range or education level can give additional information about the patients' capacity impairment, and therefore improve assessments accuracy.

\section{Conclusion}

376 Concerns about healthcare decision-making capacity will continue to grow world widely, since the prevalence of 377 dementia and other diseases related to cognitive impairment keeps increasing. One of the most relevant topics in 378 this field relates to the way capacity should be conceptualized. On one hand, clinical approaches conceptualize 379 healthcare capacity as a gradual model, according to which the patient can vary among levels of competence. In 380 this model, a person may retain capacity to consent to routine procedures, but lack competence to make decision 381 about risky treatments. On the other hand, in legal settings healthcare capacity is predominantly considered a 382 threshold competence, this is, either the person is considered to have or not have capacity to make healthcare 383 decisions [28]. A gradual model is undoubtedly more congruent with how capacity varies in real life situations, 384 where competence does not appear as a dichotomous construct [34]. However, it can be challenging to apply this approach in legal settings, where a specific judgment is required.

386 This review shows that a considerable number of instruments to assess decision-making capacity have been 387 developed in the last decades. However, decision-making capacity in healthcare still lacks a gold standard [38]. 388 In consequence, clinical judgment is still considered as the closest to a gold standard of capacity assessment [1]. 389 Nonetheless, clinical judgment, without the recourse of a standardized assessment tool, has been proved to 390 overestimate patients' capacity to make healthcare decisions [39]. Alternatively, the Mac-CAT has been pointed 391 out has a gold standard in decision-making capacity assessment [40]. Although Mac-CAT is one of the most 392 widely used instruments, some restraints must be considered, as the lack of normative data.

393 Assessment of healthcare decision-making capacity raises a few unanswered challenges. A further develop of 394 standardized tools, with normative data, and more widespread education and training in capacity assessment 395 among psychologists and other mental health professionals are needed to achieve more accurate assessments. 396 Standardized tools development should be based on a thoroughly review of relevant literature and previous 
Decision-making Capacity in Healthcare

397

1

assessment tools. Likewise, instruments development should consider experts experiences and practices, as well as gather professionals' perspectives on how to assess healthcare decision-making capacity.

Furthermore, it is considered that in order to improve healthcare decision-making capacity assessments' reliability, clear legal frameworks and guidelines regarding capacity assessments are necessary. To our view, assessments of healthcare decision-making capacity should follow specific legal procedures or guidelines that define assessment protocols, including a valid standardized capacity assessment tool with normative data, as well as a broader neuropsychologic assessment. The definition of guidelines seems to be a necessary condition to protect patients' rights of autonomy and protection.

\section{Bibliography}

1. Moye J, Gurrera RJ, Karel MJ, Edelstein B, O’Connell C. Empirical advances in the assessment of the capacity to consent to medical treatment: Clinical implications and research needs. Clin Psychol Rev. 2006; https://doi.org/10.1016/j.cpr.2005.04.013

2. Galietta M, Garcia-Mansilla A, Stanley B (2013) Assessing Civil Capacities. In: Weiner IB, Otto RK editors. Handbook of Forensic Psychology, 4th ed. New Jersey: John Wiley \& Sons; 2013. pp. 219-236

3. Grisso T, Appelbaum PS. Assessing Competence to Consent to Treatment: A Guide for Physicians and Other Health Professionals. New York: Oxford University Press; 1998.

4. Palmer BW, Salva GN, Harmell AL. Healthcare Decision-Making Capacity. In: Demakis GJ, editor. Civil Capacities in Clinical Neuropsychology. New York: Oxford University Press; 2012. pp. 69-94

5. Appelbaum P, Grisso T. Assessing patients' capacities to consent to treatment. N Engl J Med. 1988; https://doi.org/10.1056/NEJM198812223192504

6. Palmer BW, Harmell AL. Assessment of Healthcare Decision-making Capacity. Arch Clin Neuropsychol. 2016; https://doi.org/10.1093/arclin/acw051

7. Roth LH, Lidz CW, Meisel A, Soloff PH, Kaufman K, Spiker DG, Foster FG. Competency to decide about treatment or research. Int J Law Psychiatry. 1982; https://doi.org/10.1016/0160-2527(82)90013-9

8. Fitten JL, Waite MS. Impact of Medical Hospitalization on Treatment Decision-Making Capacity in the Elderly. Arch Intern Med. 1990;150:1717-1721

9. Bean G, Nishisato S, Rector NA, Glancy G . The psychometric properties of the Competency Interview Schedule. Can J Psychiatry. 1994; https://doi.org/10.1177/070674379403900804

10. Grisso T, Appelbaum PS, Mulvey EP, Fletcher K. The MacArthur Treatment Competence Study. II - 
Decision-making Capacity in Healthcare

Measures of abilities related to competence to consent to treatment. Law Hum Behav. 1995; https://doi.org/10.1007/BF01499322

11. Grisso T, Appelbaum PS (1998) MacArthur Competence Assessment Tool For Treatment (MacCAT-T). Sarasota: Professional Resource Press; 1998.

12. Marson DC, Ingram KK, Cody HA, Harrell LE. Assessing the Competency of Patients With Alzheimer's Disease Under Different Legal Standards A Prototype Instrument. Arch Neurol. 1995; https://doi.org/10.1001/archneur.1995.00540340029010

13. Tomoda A, Yasumiya R, Sumiyama T, Tsukada K, Hayakawa T, Matsubara K, Kitamura F, Kitamura T. Validity and reliability of structured interview for competency incompetency assessment testing and ranking inventory. J Clin Psychol. 1997; https://doi.org/10.1002/(SICI)1097-4679(199708)53:5<443::AIDJCLP4>3.0.CO;2-O

14. Edelstein B. Challenges in the assessment of decision-making capacity. J Aging Stud. 2000; https://doi.org/10.1016/S0890-4065(00)80006-7

15. Etchells E, Darzins P, Silberfeld M, Singer PA, Mckenny J, Naglie G, Katz M, Guyatt GH, Molloy DW, Strang D. Assessment of Patient Capacity to Consent to Treatment. J Gen Intern Med. 1999; https://doi.org/ 10.1046/j.1525-1497.1999.00277.x

16. Schmand B, Gouwenberg B, Smit J, Jonker C. Assessment of mental competency in community-dwelling elderly. Alzheimer Dis Assoc Disord. 1999; https://doi.org/10.1097/00002093-199904000-00004

17. Wong JG, H Clare IC, Holland AJ, Watson PC, Gunn M. The capacity of people with a "mental disability" to make a health care decision. Psychol Med. 2000; https://doi.org/10.1017/s0033291700001768

18. Carney M, Neugroschl J, Morrison S, Marin D, Siu A. The development and Piloting of a Capacity Assessment Tool. Artic J Clin ethics. 2001;12:17-23

19. Cea CD, Fisher CB. Health Care Decision-Making by Adults With Mental Retardation. Ment Retard. 2003; https://doi.org/10.1352/0047-6765(2003)041<0078:hcdmba>2.0.co;2

20. Vellinga A, Smit JH, van Leeuwen E, van Tilburg W, Jonker C. Competence to consent to treatment of geriatric patients: Judgements of physicians, family members and the vignette method. Int $\mathrm{J}$ Geriatr Psychiatry. 2004; https://doi.org/10.1002/gps.1139

21. Moye J, Karel MJ, Edelstein B, Hicken B, Armesto JC, Gurrera RJ. Assessment of capacity to consent to treatment. Clin Gerontol. 2007;31:37-66

22. Grisso T, Appelbaum PS. The MacArthur Treatment Competence Study. III: Abilities of patients to consent 
Decision-making Capacity in Healthcare

to psychiatric and medical treatments. Law Hum Behav. 1995; https://doi.org/10.1007/BF01499323

23. Appelbaum PS, Grisso T. The MacArthur treatment competence study. I: Mental illness and competence to consent to treatment. Law Hum Behav. 1995; https://doi.org/10.1007/BF01499321

24. Gerstenecker A, Niccolai L, Marson D, Triebel KL. Enhancing Medical Decision-Making Evaluations: Introduction of Normative Data for the Capacity to Consent to Treatment Instrument. Assessment. 2016; https://doi.org/10.1177/1073191115599053

25. Sturman ED. The capacity to consent to treatment and research: A review of standardized assessment tools. Clin Psychol Rev. 2005; https://doi.org/10.1016/j.cpr.2005.04.010

26. Kolva E, Rosenfeld B. Legal Perspectives on Civil Capacity and Competence. In: Demakis GJ, editor. Civil Capacities in Clinical Neuropsychology. New York: Oxford University Press; 2012. pp. 17-36

27. Moye J, Karel MJ, Azar AR, Gurrera RJ. Capacity to Consent to Treatment: Empirical Comparison of Three Instruments in Older Adults With and Without Dementia. Gerontologist. 2004; https://doi.org/10.1093/geront/44.2.166

28. American Bar Association Comission on Law and Aging, American Psychological Association. Assessment of older adults with diminished capacity: A handbook for psychologists; 2008. https://www.apa.org/pi/aging/programs/assessment/capacity-psychologist-handbook.pdf

29. Roth LH, Meisel A, Lidz CW. Tests of competency to consent to treatment. Am J Psychiatry. 1977; https://doi.org/10.1176/ajp.134.3.279

30. Grisso T. Competence to Consent to Treatment. In: Grisso T, Borum R, Edens J, Moye J, Otto R, editors. Evaluating Competencies: Forensic Assessments and Instruments, 2nd ed. New York: Springer; 2005. pp. $391-460$

31. Thalén L, Heimann Mühlenbock K, Almkvist O, Eriksdotter M, Sundström E, Tallberg IM. Do adapted vignettes improve medical decision-making capacity for individuals with Alzheimer's disease? Scand J Psychol. 2017; https://doi.org/10.1111/sjop.12401

32. Grisso T, Appelbaum P. Mentally ill and non-mentally-ill patients' abilities to understand informed consent disclosures for medication - Preliminary data. Law Hum Behav. 1991; https://doi.org/10.1007/BF02074077

33. Vellinga A, Smit JH, Van Leeuwen E, Van Tilburg W, Jonker C. Decision-making capacity of elderly patients assessed through the vignette method: Imagination or reality? Aging Ment Heal. 2005; https://doi.org/10.1080/13607860512331334059

34. Vellinga A, Smit J, van Leeuwen E, van Tilburg W, Jonker C. Instruments to assess decision-making 
Decision-making Capacity in Healthcare

capacity: an overview. Int Psychogeriatrics. 2004; https://doi.org/10.1017/s1041610204000808

35. Marson DC. Loss of competency in Alzheimer's disease: Conceptual and psychometric approaches. Int J Law Psychiatry. 2001; https://doi.org/10.1016/S0160-2527(01)00064-4

36. Russo S, Jongerius C, Faccio F, et al. Understanding Patients' Preferences: A Systematic Review of Psychological Instruments Used in Patients' Preference and Decision Studies. Value Heal. 2019; https://doi.org/10.1016/j.jval.2018.12.007

37. Karel MJ, Moye J, Bank A, Azar AR. Three Methods of Assessing Values for Advance Care Planning: Comparing Persons With and Without Dementia. J Aging Health. 2007; https://doi.org/10.1177/0898264306296394

38. Pennington C, Davey K, Meulen R Ter, Coulthard E, Kehoe PG. Tools for testing decision-making capacity in dementia. Age Ageing. 2018; https://doi.org/10.1093/ageing/afy096

39. Sessums LL, Zembrzuska H, Jackson JL. Does this patient have medical decision-making capacity? JAMA - J Am Med Assoc. 2011; https://doi.org/10.1001/jama.2011.1023

40. Sturman ED. The capacity to consent to treatment and research: A review of standardized assessment tools. Clin Psychol Rev. 2005; https://doi.org/10.1016/j.cpr.2005.04.010 